\title{
Inhabiting compassion: A pastoral theological paradigm
}

\begin{tabular}{|c|c|}
\hline $\begin{array}{l}\text { Author: } \\
\text { Phil C. Zylla }\end{array}$ & \\
\hline $\begin{array}{l}\text { Affiliations: } \\
{ }^{1} \text { McMaster Di } \\
\text { Hamilton, Can }\end{array}$ & $\begin{array}{l}\text { vinity College, } \\
\text { lada }\end{array}$ \\
\hline $\begin{array}{l}\text { 2Department F } \\
\text { Theology, FacL } \\
\text { Theology, Uni } \\
\text { Pretoria, Sout }\end{array}$ & $\begin{array}{l}\text { Practical } \\
\text { ulty of } \\
\text { versity of } \\
\text { h Africa }\end{array}$ \\
\hline $\begin{array}{l}\text { Research Proje } \\
\text { Project Leade } \\
\text { Project Numb }\end{array}$ & $\begin{array}{l}\text { ect Registration: } \\
\text { r: Y. Dreyer (1) } \\
\text { er: } 2546930\end{array}$ \\
\hline $\begin{array}{l}\text { Description: } \\
\text { Prof. Dr Phil Zy } \\
\text { participating ir } \\
\text { project, 'Gend } \\
\text { Practical Theol } \\
\text { Formation', dir } \\
\text { Dr Yolanda Dre } \\
\text { Department o } \\
\text { Theology, Facu } \\
\text { Theology, Univ } \\
\text { Pretoria. }\end{array}$ & $\begin{array}{l}\text { ylla is } \\
\mathrm{n} \text { the research } \\
\text { ler Studies and } \\
\text { logy Theory } \\
\text { rected by Prof. } \\
\text { eyer, } \\
\text { f Practical } \\
\text { ulty of } \\
\text { versity of }\end{array}$ \\
\hline $\begin{array}{l}\text { Correspondin } \\
\text { Phil Zylla, } \\
\text { zyllap@mcma }\end{array}$ & $\begin{array}{l}\text { g author: } \\
\text { ster.ca }\end{array}$ \\
\hline $\begin{array}{l}\text { Dates: } \\
\text { Received: } 09 \text { N } \\
\text { Accepted: } 04 \text { J } \\
\text { Published: } 31\end{array}$ & $\begin{array}{l}\text { May } 2017 \\
\text { June } 2017 \\
\text { Aug. } 2017\end{array}$ \\
\hline $\begin{array}{l}\text { How to cite th } \\
\text { Zylla, P.C., } 201 \\
\text { compassion: A } \\
\text { theological pa } \\
\text { Teologiese Stu } \\
\text { Theological St } \\
\text { a4644. https:/ } \\
\text { 10.4102/hts.v }\end{array}$ & $\begin{array}{l}\text { is article: } \\
7, \text { 'Inhabiting } \\
\text { A pastoral } \\
\text { radigm', HTS } \\
\text { dies/ } \\
\text { udies 73(4), } \\
\text { /doi.org/ } \\
73 i 4.4644\end{array}$ \\
\hline $\begin{array}{l}\text { Copyright: } \\
\text { (c 2017. The A } \\
\text { Licensee: AOSI } \\
\text { is licensed und } \\
\text { Creative Comm } \\
\text { Attribution Lice }\end{array}$ & $\begin{array}{l}\text { Authors. } \\
\text { IS. This work } \\
\text { der the } \\
\text { nons } \\
\text { ense. }\end{array}$ \\
\hline Read online: & \\
\hline 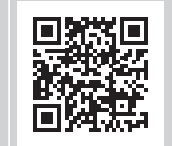 & $\begin{array}{l}\text { Scan this QR } \\
\text { code with your } \\
\text { smart phone or } \\
\text { mobile device } \\
\text { to read online. }\end{array}$ \\
\hline
\end{tabular}

Inspired by the vision of care in Vincent van Gogh's depiction of the parable of the Good Samaritan, this article offers a paradigm for inhabiting compassion. Compassion is understood in this article as a moral emotion that is also a pathocentric virtue. This definition creates a dynamic view of compassion as a desire to alleviate the suffering of others, the capacity to act on behalf of others and a commitment to sustain engagement with the suffering other. To weave this vision of compassion as a habitus rather than a theoretical construct, the article develops three phases of compassion: seeing, companioning and sighing. This framework deepens and augments a pastoral theological paradigm of compassion with the aim of inculcating an inhabited compassion in caregivers and the communities in which they participate.

\section{Introduction}

In his depiction of The Parable of the Good Samaritan, ${ }^{1}$ Vincent van Gogh orients us to the task of human concern for another which is the essence of compassion. Reflection on such a painting can heighten our understanding of the meaning of the parable, and this article uses the Van Gogh painting as a springboard for such a reflection. Pastoral theologian Paul Ballard, drawing on the work of Jane Dillenberger, offers that there are three interlocking processes when reflecting on a work of art: the simple iconographic content; the form or composition or structure; and the meaning (Ballard 2003:405). Ballard invites us to think about the importance of all three processes when viewing a work of art, but in particular the last step. Ballard explains, 'Here the viewer moves to being a participant; letting the painting speak and responding to it ... Art can provide a pastoral resource that has been underused' (Ballard 2003:408). This article will interact with the Parable of the Good Samaritan (Lk 10:25-37), especially as it is depicted in the van Gogh painting. The paradigm that emerges includes three phases of compassion: seeing, companioning and sighing. To inculcate an inhabited compassion, this article seeks to awaken the senses with a paradigmatic orientation to the suffering of the other and evoke a response that is more 'a way of being' than a series of steps. The call of the church as the compassionate community of God is to awaken to this responsibility of compassion and to learn how to inhabit the contours of active help in the midst of intractable problems and pain. However, the root understandings of the nature of compassion are less obvious than one might assume. This article seeks to build on the notion of compassion that has been articulated by Wayne Whitson Floyd Jr., as a dynamic process which includes: (1) a disposition of solidarity to the neighbour's suffering; (2) the action of entering into the context of that suffering as one's own; and (3) a commitment to overcoming the cause of the suffering itself (Floyd 1993:48). Such a dynamic process overcomes the settled notion of compassion as either an incidental occurrence or merely an individual activity. The notion of compassionate solidarity as a process requires further reflection, however, as it indicates phases of compassionate involvement and orientation to the suffering of another.

Before moving further, it is important to develop a working understanding of compassion. I begin with the assessment of Steven Sverdlik who offers that compassion is a distinctive 'moral emotion' (Sverdilk 2008:2). In his view, moral emotions contain both a belief and a desire. In the case of compassion there is a belief that the suffering or misfortune of another is great and the desire is to relieve the suffering ('for the sake of the sufferer') (Sverdilk 2008:5). This idea of compassion as a moral emotion is supported by Roger Crisp who argues that the heart of compassion as an emotion is what we feel at the misery of suffering of others' (Crisp 2008:237). Crisp argues that the dominant view of compassion as a cognitive virtue (Nussbaum) is mistaken that, 'what is central to compassion is the non-cognitive element of pain or distress at the pain or distress of others' (2008:240). Sverdik's category of 'moral emotion' is a strong one in that it integrates some of the 1.Vincent van Gogh's painting of the Good Samaritan parable can be viewed at: http://www.artbible.info/art/large/595.html 
characteristic virtue traits of Aristotelian thought with the emotional construct of compassion as a feeling of response to the suffering of others. Therefore, Crisp will argue that compassion is both an emotion and a virtue which is indicated by both action and feeling. So, in Crisp's view, 'the compassionate person will not only feel compassion, but act compassionately' (2008:241). Crisp creates categories of the virtues which he identifies as pathocentric, praxocentric and orexocentric, compassion being a pathocentric virtue (Crisp 2008:242).

There is some debate about the necessity of Sverdlik's opinion that the suffering of others must be 'great'. This is a common assumption about compassion that Crisp challenges in his interpretation of the emotion/virtue of compassion. In Crisp's view, there is no reason to accept what is commonly referred to as 'the seriousness requirement' (2008:234). In his view, the feeling of compassion is equivalent to the seriousness of the situation encountered. Crisp defends this view by stating:

Compassion is a feeling or emotion analogous to fear or anger, and there is no a priori reason to expect some threshold at which it cuts out. Compassion is felt at the misery of others, and if their misery is minor then the default assumption must be that the compassion felt will also be minor or faint. (2008:235)

This article, then, will take the view that compassion is a moral emotion that is also a pathocentric virtue. As such compassion evokes deep feelings of pain or distress at the pain or distress of others. Compassion will result in a feeling of shared anguish, a desire to see the situation changed and actions that alleviate the root cause of the suffering observed.

This view of compassion must not, however, be limited to either an individual response or a single incident. The idea of dynamic process of compassion in Floyd's argument is a crucial point. In Floyd's schema, compassion begins with a disposition of solidarity with the suffering other, moves to action of entering into the context of that suffering as one's own and carries a commitment to the alleviation of the causes of suffering identified. This dynamic process carries the idea of compassion beyond the feeling/desiring/acting paradigm to an ongoing participation in the situation of suffering identified.

From a Christian theological perspective Nouwen, McNeill and Morrison expand on this idea and offer that compassion is 'the center of Christian life' (1983:8). They conclude that this radical orientation to care for those who are suffering (compassion literally means 'to suffer with') is demonstrated in the compassion of Jesus. With this in view they offer a description of what compassion means for the Christian life:

It is not a bending toward the underprivileged from a privileged position; it is not a reaching out from on high to those who are less fortunate below; it is not a gesture of sympathy or pity for those who fail to make it in the upward pull. On the contrary, compassion means going directly to those people and places where suffering is most acute and building a home there. (Nouwen et al. 1983:27)
These ideas of compassion will therefore frame our understanding in this article. Firstly, that compassion is a moral emotion that holds the conviction that all suffering, however small or large, deserves response and includes a desire for relief from that suffering 'for the sake of the sufferer'. Secondly, that compassion is a pathocentric virtue that evokes deep feelings of pain and distress at the pain and distress of others. Thirdly, that compassion is a dynamic process that begins with identification with the suffering of others and moves to action, sympathy, and alleviation of the causes of suffering identified. And finally, that, from a Christian theological perspective, compassion is a radical call and orientation to move into the situation of the suffering of others with active help.

As the title of this article indicates, the goal or aim of this essay is to inculcate an inhabited compassion. Pastoral theology has demonstrated a deep concern for such a habitus in the persons who embody pastoral care and the communities in which they act and participate. The idea of compassion as a core construct for pastoral theology guides this vision and animates the theory of compassion described above. The enactment of compassion as a core construct of authentic pastoral action (both individually and communally) guides the following description. While compassion is a fundamental human emotion, the performance of this practice demands new ways of approaching the inculcation of such responses in pastoral theology.

Yolanda Dreyer with Philip Nolte underscores the importance of the idea of habitus as fundamental to such an approach to practical theology. They remind us that Pierre Hadot argues, 'that ancient philosophers were not only interested in knowledge for the sake of knowledge, but 'always intended to produce an effect, to create a habitus within the soul, or to provoke a transformation of the self'. In this sense, practical reason has precedence over theoretical reason' (Dreyer \& Nolte 2010:5). In what follows this article argues for a three-fold habitus of compassion as seeing, companioning and sighing.

\section{Seeing: The first phase of compassion}

The striking use of 'seeing' language is central in the biblical parable of the Good Samaritan. According to the text of Luke $10: 30-35,{ }^{2}$ all of the travellers on the road to Jericho 'saw' the man who was attacked and beaten by robbers. The priest 'saw the man' (31); the Levite 'saw him' (32) and the Samaritan also 'saw him' (33). The difference between the three 'sightings' is that the Samaritan, 'when he saw him, he took pity on him' (33). The link here between seeing and compassion (or lack of it) is the key focus of this first phase of compassion.

Seeing is a metaphor that comes to us from the arts but it is frequently being incorporated into pastoral theology

2.Unless otherwise indicated all biblical citations are from the New international Version. 
and ethics. Paul Ballard (2003) outlines the significance of seeing in pastoral theology when he states:

To see is to locate oneself in space. It sets us in a horizon ... To see is to indwell the world; it is to recognize the givenness of our situation, our 'thrownness' from which we cannot escape and which creates us. But it is we who see. It is impossible to take in all that our senses experience. The eye has to focus and therefore select. (p. 407)

While the visual dimension has often been subsumed under the relationship of the fine arts to theology, more recently UK practical theologian Stephen Pattison (2007) examines the visual aspects to life more broadly. He states:

The sense of sight has often been regarded as the most important and sophisticated of the senses. It is closely linked with reason, thought and mentation - hence the proliferation of sight and light-related words to describe aspects of the intellectual. (p. 14)

But Pattison expands his point of view indicating that the visual dimension affects all of life. In Pattison's view the visual dimensions of life have importance for both the ethical life and the responsibilities that emerge from this. While we must avoid the temptation to privilege 'sight' over the other senses, the elements of seeing well can expand our approach to compassionate pastoral theology. We must be able to see clearly and to have in view all of the dimensions of life that come into our horizon. How then can we'see' compassionately what is in front of us?

Undoubtedly, the capacity to see is a primary sense of being human and is a relevant dimension of pastoral theological inhabitation. This first phase explores the human capacity for seeing compassionately and then explores the implications for a more robust or comprehensive understanding of compassion.

In his book, Vision and Virtue, Stanley Hauerwas (1981) articulates the importance of the metaphor of seeing for the moral life when he states:

... once the question of 'the ethical' is broadened to include vision, we can comprehend that being a Christian involves more than just making certain decisions; it is a way of attending to the world. It is learning 'to see' the world under the mode of the divine ... This learning requires training of our attention by constantly juxtaposing our experience with vision. (p. 45)

Attending to the world is a crucial dimension of moral seeing and the root of compassion. If compassion is a moral emotion that enacts response by virtue of the feeling of sympathy with the plight of others, seeing is certainly primary. Inculcating the pathocentric virtue of compassion requires, first, to strengthen our capacity to see well. But what is it that we are to keep in view?

Seeing enlightens us to what the 'situation is'. In his seminal article on the critical nature of the situational, Edward Farley states, 'All human beings exist and act in situations and engage in the interpretation of situations' (Farley 1987:12).
He then offers this definition, 'A situation is the way various items, powers and events in the environment gather together so as to require responses from participants' (Farley 1987:12). Farley points out that situations can be localised to an immediate context (the situation of a specific family) or extended to a global context (the ecological situation of the whole planet). In the analysis of these complex and multivalent situations Farley calls for four tasks in their interpretation:

1. Identifying the situation and describing its distinctive and constituent features.

2. Probing the situation in order to re-member the disguised repressions of the past.

3. To locate the situation within its larger situation, thus offering an inter-situational explanation.

4. Discern the situation's demand from a theological perspective (Farley 1987:12-14).

Farley's insightful tasks inform the core concept of 'seeing' as the first act of compassion. Seeing enlightens us to what the situation is - a core commitment of compassionate responsibility of the individual and the community. Helping is often considered to be the first act of compassion, but seeing precedes helping and allows for moral vision to unfold. Seeing a complex situation is another way of orientating to the four-fold tasks of identifying, probing, locating and discerning a situation. If we are to offer compassionate responses we must cultivate the capacity to behold what is in front of us and to carefully unpack the implications for our response. Furthermore, the task of seeing the situation requires 'complexifying' or, through critical reflection to 'reveal that it [the situation] is in fact complex and polyvalent' (Swinton \& Mowat 2006:13).

This identifies a first issue of inculcating compassion, namely, that we believe we are good at seeing when in fact we are not. Most situations are quite complex, and our failure to recognise this can truncate our response and hinder the kind of comprehensive action that the situation demands. Ronald Richardson (1996) remarks about the tendencies of oversimplifying our observations of a complex situation when he states:

We observe a few things that happen 'out there', fail to see or even ignore other things, and create a story for ourselves explaining what it is all about. We might think of ourselves as good observers, but in fact most of us are not. We go right from a few pieces of observational data into our beliefs about what is going on and why people are doing what they do. (p. 37)

Compassion requires a disciplined seeing that will identify all of the dimensions of the situation we have encountered.

Therefore, a first movement in our compassionate response is to look at the scope of the situation by careful observation, reflection and assessment. The observation of the situation requires careful attention to the needs of the situation, the actions that the situation demands, and some evaluation of the seriousness of the needs that are presented. Assessment is 
a crucial aspect of 'seeing' the situation. This involves artful attention as described by Simone Weil (1950):

Love for our neighbor, being made of creative attention, is analogous to genius. Creative attention means really giving our attention to what does not exist. Humanity does not exist in anonymous flesh lying inert by the roadside. The Samaritan who stops and looks gives his attention all the same to this absent humanity, and the actions which follow prove that it is a question of real attention. (p. 149)

Seeing involves this artful attention as the primary orientation to a compassionate response. For Weil, such unmixed attention orients us to God, shapes our intentions according to God's purposes, and opens up the infinite value of personhood in every compassionate encounter (Weil 1952:117). Furthermore, attention in Weil's schema 'involves a self-diminishment in which one's desire becomes wholly fixated on the existence of the other as other' (Hollingsworth 2013:211). Authentic compassion, in her view, requires genuine attention to a suffering. This entails both an openness and receptivity to the pain of the other and an entry into the very experience of the other as one's own.

Situations can be bewildering. Therefore, 'seeing' the situation must also include weighing all the facts that present themselves to us. What has happened here? This involves taking in all of the information that can help us to see the event or situation most completely. Such assessment involves: (1) identifying the needs that have emerged in the situation; (2) describing the resources required to meet the needs of the situation; (3) evaluating the hidden realities behind the situation and (4) weighing the implications of the situation as it seems to be. There can be no way to fully account for all of the dimensions of any situation of suffering. However, keen observations, careful attention to the details of what is unfolding, and some accurate record of the elements that are presented to us will help to determine the range of responses that compassionate intervention may require.

This process of looking into a situation is complex and requires further reflection. Looking may also be described as an imaginative act of anticipating 'what might be'. This involves 'looking ahead', as it were, and anticipating where things might be going and how to alleviate the emerging needs that will inevitably flow from any event or crisis. ${ }^{3}$ Seeing moves beyond looking. We move from being keen observers to careful assessors to creative intervenors. In some relation to each other, these are the three actions of seeing: attention, reorientation and perspective.

It was Paul Tillich who suggested that the idea of attention requires a deep rooting in ultimate reality and a solid grounding in experiences of life. He states, 'ontology presupposes a conversion, an opening of the eyes, a revelatory experience. It is not a matter of detached observation, analysis

3.Donald Capps reveals a link that verifies this in Erik Erikson's Toys and Reasons results in two forms of vision: 'seeing' and 'foreseeing'. In Erikson's explanation this in involves, 'the capacity to see what is before us, here and now, and foresee what, if one can only believe it, might yet prove to be true in the future (Erikson, Toys and Reasons: 46). or hypothesis' (Tillich 1964:65). Our eyes can only be opened when we indeed are rooted in ultimate reality and grounded in experiences. The failure of the Priest and the Levite in the parable of the Good Samaritan to 'see' the situation is also a problem for us. We need to have our eyes opened - to truly look and see the reality that is presenting itself to us.

The aspect of reorientation demands a moral reappraisal of the situation. This implies the widely-noted problem of indifference or apathy in the complex responses to suffering. Moral blindness or a reduced capacity to see the problem is an acute dimension of moral seeing. S. Dennis Ford observes that, 'indifference is the failure to see, to acknowledge or to act on behalf of others' (Ford 1990:12). In all of these ways we fall short of measuring the seriousness of the situation presented to us and we fail to enact the responses required. It is not enough to recognise the compassion requires/ demands a resourceful response, but it also shifts the moral weight from 'seeing' to 'sharing' in the suffering of others. Any pastoral theological response to suffering calls for a reassessment of our moral responsibility to see, to acknowledge and to act.

Seeing is an essential component of compassion. In Christ and the Moral Life, ethicist James Gustafson (1968) outlines how seeing things from the perspective of Christ is at the core of the Christian life. He explains:

The word 'perspective' is drawn from the sphere of its normal usage, that is visual experience, and suggests that the point from which things are seen and observed determines what is seen and what is not seen, which aspects of what is seen are outstanding, which are shadowed and which are clear, what attracts attention and what is subdued in attention. It has come to be used to refer to more than strictly visual experience as well. Perspective is used to refer to the state of the observing subject; to his [sic] preferences for certain things, to his fundamental vocabulary for describing and evaluating what he observes, his criteria for rational judgment, and his values that determine his affective responses. Sometimes the word 'understanding' has been used to cover these things ... The notion of perspective or understanding has been used, and can still be used, with care to interpret a basic aspect of the Christian moral life. (p. 242)

The Christian way of seeing, for Gustafson, involves the 'perspective and posture of Jesus Christ' (1968:244). This demands a reorientation of our seeing that includes a divine dimension. Such an orientation or perspective requires a spiritual commitment and a new way of seeing. While seeing is an essential first act of compassion, for Simone Weil compassion is an enactment of union with God. Compassion is not simply a response to seeing the suffering of others but rather through attunement to affliction we enact what Weil calls, 'compassion's impossibility' (Hollingsworth 2013:218) namely to enter into the ineffable situation of the mute sufferer with the love of God. This invites a second movement, in our paradigm of inhabiting compassion, the movement of 'companioning'. 


\section{Companioning: The second phase of compassion}

One of the less developed notions from the parable of the Good Samaritan is the concept of companionship. In the biblical narrative in Luke's gospel, we read of the threefold commitment of the Samaritan to care for the suffering neighbour: arriving, being with and staying:

But a Samaritan, as he traveled, came where the man was; and when he saw him, he took pity on him. He went to him and bandaged his wounds, pouring on oil and wine. Then he put the man on his own donkey, brought him to an inn and took care of him. The next day he took out two denarii and gave them to the innkeeper. 'Look after him,' he said, 'and when I return, I will reimburse you for any extra expense you may have.' said, 'and when I return, I will reimburse you for any extra expense you may have.' Luke 10:33-35

Entering into the situation of the suffering other is at the centre of compassionate action. Among the more persistent impediments to authentic pastoral action in the situation of suffering is this phase of companionship or entering into the suffering of others with active help. As I have argued elsewhere:

We need to see at the beginning of our efforts toward compassion that there is an unconscious move away from those who suffer. This subtle despising of the afflicted can be reinforced and, despite feelings of empathy or pity, may result in the avoidance of the reality of the situation of those who suffer. (Zylla 2012:94)

We must, therefore, distinguish between the emotions of pity and sympathy which, while related to compassion, fail to inhabit the more nuanced aspects of desire to see the suffering of others eliminated and the action of responsible engagement with the situation and its constituent demands. This requires a threefold enactment of response to the situation in front of us: the art of arriving, the ministry of 'being with' and the risk of staying.

\section{The art of arriving}

Upon seeing the serious situation of a neighbour, we are immediately confronted with a choice which is the first step of compassionate companionship. The choice is to 'move towards' or to 'move away' from suffering. It is deliberately one or the other. Compassion, in its essence, includes the art of arriving. The compassionate impulse begins with seeing, but it moves to action as we show up in the situation with active help. The essence of compassion, at least as we encounter it in the Parable of the Good Samaritan that the Priest and the Levite both 'saw' and 'passed by' while the Samaritan, upon seeing the wounded man, took pity on him and moved towards him with active help.

There are barriers, however, to showing up in the situations and dilemmas of others. Any number of things can prevent us from inaction in the face of a situation of the needful neighbour. While further reflection may reveal more barriers,
I would identify three for consideration: Preoccupation, miscalculation and fear.

Preoccupation and busyness are enormous inhibitors of compassion. We fill our lives with activities and tasks, many of which are mundane and not very extraordinary. However, these preoccupations distract us and indirectly reinforce our indifference to the situations by their sheer power over our lives. As S. Dennis Ford puts it 'the competition for people's attention, the avenues of ethical avoidance, are both numerous and constant' (Ford 1985:32). In view of this tendency to fill our lives, it is clear that inculcating compassion requires a further step of undoing the process of what Ford calls, 'habituation'. 'We fail to act morally', says Ford (1985):

because we fail to see anew the demands and possibilities of a situation; we see what we've always seen, we do what we've always done. Ethical decisions are secondary to our a priori routines and presuppositions. (p. 33)

So how, then, do we heighten our sensibility to the suffering of others and overcome the busyness and preoccupations that inhibit our compassion?

In his insightful work, Crossing the Unknown Sea, poet and philosopher David Whyte argues for what he terms 'a good waking'. The spiritual practice of attention requires alertness to the world in front of us and a capacity to stir our senses towards the needs that we encounter in everyday experiences. Whyte (2001) describes it this way:

A good waking is a waking full of hearing, subtle seeing, and anticipation ... A good waking has us listening and seeing in such a way that we are not immediately the center of the world, where we have time for the blessing of things as they are. A good waking is a spacious entry into a day where we are especially free from everything that needs to be done ... We should apprentice ourselves to coming awake, treat it as a form of mastery. (p. 187)

Waking implies an unlearning of the habit of preoccupation. Apprenticing ourselves to the horizon that unfolds in front of us and embracing what it yields, good or bad, is part of what the practice of compassion requires.

A second barrier to compassion could be construed as a miscalculation of the importance of the situation in front of us. In the professional practice of nursing, Margreet van der Cingel (2009) suggests that gathering accurate information is crucial to discerning the situation's demand. She says:

One needs to see what is salient ... One needs to know the significance of the loss as the other person sees it. Without specific information this is a troublesome task because of the subjective meaning of a loss to someone. (p.128)

Our capacity to critically discern our own perceptions of a situation and to bracket judgement about the situation we are encountering are a vital part of authentic compassion. It is not enough to simply position ourselves as sympathetic caregivers. Rather, we must engage in the gathering of 
information that cultivates an understanding of the meaning of the situation we are in and its contextual features.

Practical theology has a deep commitment to contextual engagement and the discovery of the concreteness and complexity of the situations in which we enact pastoral concern. The action of recalibration and reorientation to the specifics of the situation calls for heightened attention and scrupulous investigation. We must know ourselves in the situation and we must learn to see what is in front of us accurately. For a situation of a counsellor with a client, Headley, Abbott and Sapp (1993) argue for a creative exploration of the situation, stating:

In enhancing the power and coloration of his or her abilities to experience the client's suffering in a vicarious manner, the counsellor can engage in a wide variety of exercises. Some of these might include engaging in creative expression which help move out of self-centeredness into another reality. According to Piper, forms of creative expressions such as music, painting, fiction, and first-person narrative accounts enhance one's ability to imagine modally another's state even when the compassionate person has not had the experience of the sufferer. (p. 144)

Compassion requires that we enlarge our range of emotional responses and incorporate new information that constructs the meaning both of the experiences we are exploring and the encounters we are having with those to whom our compassion is directed.

A third barrier to compassion is fear and anxiety. Not knowing what to expect and not being able to control the outcomes of a situation can be anxiety producing. There are good reasons to be concerned for one's own safety, for unknown outcomes of a situation and for any number of threats that may emerge in a situation of compassionate outreach. While it is of the essence to 'go to the people and place where suffering is most acute', there are real dangers, concrete problems and credible threats that must be addressed for compassion to be enacted.

\section{Stephen Bein (2013) reminds us that:}

compassion extends inward as well as outward. If I am a compassionate person, I am concerned for my own well-being as well as for that of others. This does not allow me to ignore others' interests in favour of my own, but by the same token it also does not justify letting others' interests run roughshod over mine. (p. 142)

Jean Vanier (2008) speaks about the way anxiety can cripple our compassion:

There is a freedom that I sense exists but that I do not have. I cannot always describe it but I do want it. I sense that I still have a long road to walk in order to reach this freedom. I see the goal but I am not yet there. I love and want it but sometimes I am frightened of the road I must take ... I am frightened of the disappearance of my walls of defense, sensing that behind them there is an anguish and a vulnerability that will rise up. I see that I still cling to what people think of me and am fed by the way people love, want and admire me. If all that feel away, who would I be? ... Is that not the freedom that Jesus announces in his charter of the Beatitudes, when he talks of the blessedness of those who are persecuted, or when he says, 'Woe to you when people speak well of you?'. (pp. 118-119)

The art of arriving is a crucial dimension of compassion. While the situation is tenuous and complex, the need for companionship and human care is greater. The courage to act, to encounter the one who is 'other' but who is in pain and distress, is one of the most noble acts of humanity.

\section{The ministry of 'being with'}

'Being with' another is also a feature of compassion. We offer ourselves in friendship, in kindness and in acts of genuine concern for the welfare and flourishing of another person. In this action of companioning with others we enter into their situation, experience it as our own and thereby penetrate the inner loneliness that resides in suffering. Being with a person who is in distress and sharing their discomfort and pain is part of the essential ministry of compassion.

Milton Mayeroff (1971) offers this understanding of the transaction of personal encounter that such compassion yields:

When the other is with me, I feel I am not alone, I feel understood, not in some detached way but because I feel [this person] knows what it is like to be me. I realize that [the caring other] wants to see me as I am, not in order to pass judgment on me, but to help me. I do not have to conceal myself by trying to appear better than I am; instead I can open myself up [allowing this person to] get close to me, and thereby [making it easier] for [the caring other] to help me. (p. 31)

The offer of friendship and companionship is an important response of compassion. John Swinton (2007) comments on the vitality of hospitality and friendship in his book, raging with compassion when he states:

Friendship is a basic and vital human relationship that forms the social fabric of our lives. It is through friendships that we discover our identity, gain our sense of value and place in the world, and learn what it means to participate in community. (p. 216)

If the parable of the Good Samaritan teaches us anything, it is that the neighbour is the nearest person in need. Our capacity to offer our presence and our friendship to those who are acutely diminished by life's strain is of the essence of the compassionate life.

\section{The risk of staying}

Compassion includes entering into the suffering of others (the art of arriving) and it means learning to be with them in the complexity of their situation ('being with'). However, there is a third dimension. Compassion must also be about learning to stay with others in their ongoing need. Showing up and being with require this third complementary action of staying and keeping vigil. 
In his hour of greatest need, Jesus calls on the friendship of those who loved him. 'Stay here and keep watch with me' (Mt 26:38). In his sorrow, and his deeply distressed state, Jesus required the companionship of his friends. Companionship includes the risk of staying.

There are sacred moments in compassionate ministry where leaving is no longer an appropriate form of caring. These moments call for the community of compassionate care to keep vigil - to wait with patient hope. One of the most helpful things we can do in compassionate ministry is to stay with people in their greatest trials of life. This is true not only for hospice care and the end of life but for those crucial times when being alone would be crushing. In this situation, compassionate ministry means 'keeping vigil'.

Keeping vigil includes intercession for others in their dire situation. It also requires acts of caring and helpfulness to alleviate the suffering that can be assuaged. Compassion calls for a community that is vigilant, from the Latin vigilia, 'wakeful' and 'alert'. If compassion is to be enacted in our communities it will require a long view and a commitment to staying. This is one of the remarkable features of the parable of the Good Samaritan - he stayed with the wounded man in his need and he continued to practise compassion long into the healing process.

There is a profound effect of companioning with others who are going through troubles and affliction. However, compassion is not simply a momentary entry into the suffering of others. It is an enduring 'being-with' others. Compassion reminds us that in sharing life with others we redeem the time, we reorient to belonging, and we awaken to lucid moments about our fundamental purpose - eternity breaks into our long, dreary days of preoccupation and busyness. Pastoral theologian John Swinton (2012) articulates this meaningful redemption of time when he states:

Time provides the existential space within which we learn to love and care for one another. But time needs to be sanctified, redeemed, and drawn into the service of God. We do this by simply slowing down and reclaiming time for its proper purposes. To learn to be in the present moment is to learn what it means to redeem time. (p. 252)

Staying may be riskier and harder than arriving or being with. This aspect of compassion is core, however, to the fabric of concern that can be identified with authentic compassion. As Floyd (1993) states:

A theology of compassion must move beyond solidarity with suffering to those active commitments whose goal is God's redemptive purpose amongst creation. This will always demand the faith and courage voluntarily to displace oneself for any secure, privileged context, to meddle dangerously in adversity, to interfere at person risk in wrongdoing, to be unpopular due to one's intolerance with any suffering for the wrong reasons. It will never be easy. But it rests on the divine promise, wrought from God's very being, that 'Everything' perhaps especially the suffering of genuine compassion, 'is grace'. (p. 63)
I have stated the central importance of companioning and would reinforce this with comments I have made in another volume:

Telling people that they are not alone in their suffering is not enough. We must demonstrate our care through the acts of showing up in their lives. At its core, ministry to the suffering means coming near to their time of grave concern and anguish. The activity that we must generate as the compassionate community of God is the capacity to discern where the greatest needs are and simply to show up. In this way we dispel the dark cloud of abandonment and rejection, enabling suffering persons to experience themselves as loved and cared for by others. (Zylla 2012:173)

\section{Sighing: The third phase of compassion}

Before we are able to verbalise the suffering of others in sensitive articulation, we must enter into the wordlessness of their anguishing situation and dwell there in the unknown depths. A fitting metaphor for this would be 'sighing'. We sigh when we cannot say. The sheer powerlessness to speak out what we are living is too great and the 'groans are too deep for words' (Rom 8:26).

Compassion involves this deeper dimension of intercession, prayerfulness and expressing the dimensions of suffering that are unspeakable. I would like to conclude this essay with three dimensions of sighing. The first of these is 'sighing as desperate prayer'. When the disciples were overwhelmed they lost their ability to pray. Such is the ministry of compassion. When we are overwhelmed by the sorrow, by the anguish and by the hardship of another's situation, it is difficult for us to pray. We need to learn to sigh. Sighing is the sign of desperation - a soul that is languishing and in need of God. When we sigh with those who suffer, we demonstrate a solidarity with them that few other actions on our part can convey. This calls for a deeper theology and practice of prayer. Most people still think of prayer as asking God for help. However, there are many kinds of prayer and at the root of true desperate praying, is the sigh of the inner spirit the last gasping reach of humanity to God who hears every whisper and every heavy-hearted yearning breath.

In the text of Romans we see the embedded nature of groaning and sighing in the spirituality of prayer. The Greek word used in Rom 8:23 is stenazo, which means 'to groan within oneself'. It can also be translated 'to sigh' or 'to pray inaudibly'. If we imagine the sigh as the weakest type of groan and inaudible prayer, we may come close to the desperation that such a concept conveys. Before wordarticulation, sighs.

In our compassionate coming-along-side-of those who suffer, we may discover that our initial solidarity is far from the depths of the experience of the person in front of us. Entering into that suffering requires a shared breathing, a murmuring of hearts, and in some expressions of the Greek idea of stenazo there can also be the feeling of grief and anger. Compassionate 
sighing is not an easy non-expressive distance. Rather, it is a call to the longing/yearning for wholeness and care. Compassionate prayer requires sharing in the groans of those with whom we have come into solidarity.

The ministry of sighing can lead to greater articulation of the situation of suffering as we embrace the situation of the other in distress as our own. I close with three forms of what Henri Nouwen calls, 'sensitive articulation' (Nouwen 1972:39). The first of these is learning the art of lamentation or the cry of anguish. This calls for a mature theology of lament and complaining to God. The Hebrew scriptures are full of complaints to God, and there are legitimate needs that should be expressed and lamented. This calls not only for permission to lament, but for a theology of lament and complaint - that we learn how to cry out to God with our deepest concerns. Secondly, it is crucial to say how bad things are. This is expressed so well by Nicolas Wolterstorff in his book, Lament for a Son. Wolterstorff (1987) offers:

\begin{abstract}
... please: Don't say it's not really so bad. Because it is. Death is awful, demonic. If you think your task as comforter is to tell me that really, all things considered, it's not so bad, you do not sit with me in my grief but place yourself off in the distance away from me. Over there you are of no help. What I need to hear from you is that you recognize how painful it is. I need to hear from you that you are with me in my desperation. To comfort me, you have to come close. Come sit beside me on my mourning bench. (p. 34)
\end{abstract}

Finally, there must be a commitment to express the ineffable in community. If our groaning is in cooperation with God's spirit, and it resounds in the groaning of creation, then it must also be a sighing that is performed in community. Compassion means coming together in the situations of life's most difficult moments and to sigh together, asking for God to protect, to intervene and to provide. Henri Nouwen describes the nature of the compassionate community this way:

When we form a Christian community, we come together not because of similar experiences, knowledge, problems, color, or sex, but because we have been called together by the same Lord ... Life in community is a response to vocation ... Thus we see how voluntary displacement leads to a new togetherness in which we can recognize our sameness in common vulnerability, discover our unique talents as gifts for the upbuilding of the community, and listen to God's call, which continually summons us to a vocation far beyond the aspirations of our career. (Nouwen et al. 1983:85)

\section{Conclusion}

This article has explored the nature of compassion and its implications for pastoral theology in a paradigmatic portrayal of seeing, companioning and sighing. The idea of compassion as a moral emotion and a pathocentric virtue govern the approach taken here. However, this is modified by the insistence that the notion of compassion requires a dynamic process that enacts the desire to help others and to alleviate the source of their suffering by actions of solidarity that including coming near, staying near, and offering sympathetic and compassionate prayer. The pastoral theological approach to compassion demands that all of the complexities of the multivalent situations be explored while staying near to the suffering other as friend or companion in an action of authentic hospitality. The nature of the Christian life as a compassionate protest of suffering and the alignment with those who are experiencing distress and pain calls for a renewed emphasis on entering the liminal places of deepest concern and staying tethered to a compassionate engagement without fear. The barriers to such compassionate involvement require creative and diligent response so as to overcome our penchant to preoccupation, distraction and fear of the unknown. The tendency to reinforce indifference or to move away from suffering is addressed, and strategies for a sustained engagement with the suffering of others are offered as one perspective on the important ministry and conceptualisation of compassion. The aim of this article has been to demonstrate what inhabiting compassion might mean, thereby moving it from a conceptual framework to an operationalised paradigm of spiritual and pastoral theology of compassion. Underscoring the need for reorientation and imaginative response, the article draws on the images of Vincent van Gogh's depiction of the parable of the Good Samaritan (Lk 10:25-37).

\section{Acknowledgements Competing interests}

The author declares that he has no financial or personal relationships which may have inappropriately influenced him in writing this article.

\section{References}

Ballard, P., 2003, 'Art and pastoral care', The Expository Times 114(12), 405-409. https://doi.org/10.1177/001452460311401204

Bein, S., 2013, Compassion and moral guidance, Monograph No. 23, Society for Asian and Comparative Philosophy, University of Hawai'I Press, Honolulu.

Crisp, R., 2008, 'Compassion and beyond', Ethical Theory and Moral Practice 11 233-246. https://doi.org/10.1007/s10677-008-9114-x

Dreyer, Y. \& Nolte, S.P., 2010, 'The paradox of being a wounded healer: Henri J.M. Nouwen's contribution to pastoral theology', HTS Teologiese Studies/Theological Studies 66(2), 8, Art. \#861.

Farley, E., 1987, 'Interpreting situations', in L.S. Mudge \& J.N. Poling (eds.), Formation and reflection: The promise of practical theology, pp. 1-26, Fortress Press, Minneapolis, MN.

Floyd, W.W. Jr., 1993, 'Compassion in theology', in G. Sapp (ed.) Compassionate ministry, pp. 35-63, Religious Education Press, Birmingham, Alabama.

Ford, S.D., 1985, 'The eccentricity of ethics: A typology of moral indifference', Perspectives in Religious Studies 12(1), 31-38.

Ford, S.D., 1990, Sins of omission: A primer on moral indifference, Fortress Press, Minneapolis, MN.

Gustafson, J., 1968, Christ and the moral life, University of Chicago Press, Chicago, IL.

Hauerwas, S., 1981, Vision and virtue: Essays in Christian ethical reflection, 2nd ed., University of Notre Dame Press, Notre Dame, IN.

Headley, A.J., Abbott, J.B. \& Sapp, G.L., 1993, 'Compassion in religious counseling', in G.L. Sapp (ed.), Compassionate ministry, Religious Education Press, Birmingham, AB.

Hollingsworth, A., 2013, 'Simone Weil and the theo-poetics of compassion', Modern Theology 29(3), 203-229. https://doi.org/10.1111/moth.12034

Mayeroff, M., 1971, On caring, Harper Collins Publishing, New York.

Nouwen, H., 1972, The wounded healer, 2nd edn., Doubleday Publishing, New York.

Nouwen, H., Morrison, D. \& McNeill, D., 1983, Compassion: A reflection on the Christian life, Doubleday, New York.

Pattison, S., 2007, Seeing things: Deepening relations with visual artefacts, SCM Press, London. 
Richardson, R.W., 1996, Creating a healthier church: Family systems theory, leadership, and congregational life, Fortress Press, Minneapolis, MN.

Sverdlik, S., 2008, Compassion and sympathy as moral motivation, Cary M. Maguire Center for Ethics and Public Responsibility Occasional Papers, Paper 3.

Swinton, J., 2007, Raging with compassion: Pastoral responses to the problem of evil, William B. Eerdmans Publishing Company, Cambridge, UK.

Swinton, J., 2012, Dementia: Living in the memories of God, William B. Eerdmans Publishing Company, Grand Rapids, MI.

Tillich, P., 1964, Theology of culture, Oxford University Press, London. van der Cingel, M., 2009, 'Compassion and professional care: Exploring the domain', Nursing Philosophy 10, 124-136. https://doi.org/10.1111/j.1466-769X.2009.00397.x
Vanier, J., 2008, Becoming human, 2nd edn., Harper Collins Press, Scarborough, ON. Weil, S., 1950, Waiting for God, Routledge and Kegan Paul, New York.

Weil, S., 1952, Gravity and grace, transl. Emma Crawford \& Marion von der Ruhr 1st English Edition, Routledge and Kegan Paul, London.

Whyte, D., 2001, Crossing the unknown sea: Work as a pilgrimage of identity, The Berkley Publishing Group, New York.

Wolterstorff, N., 1987, Lament for a son, William B. Eerdmans Publishing Company, Grand Rapids, MI.

Zylla, P.C., 2012, The roots of sorrow: A pastoral theology of suffering, Baylor University Press, Waco, TX. 